\title{
Stephan J. Joubert (South African academic and visionary): His response to questions related to his academic views
}

\begin{tabular}{|c|c|}
\hline \multicolumn{2}{|c|}{ 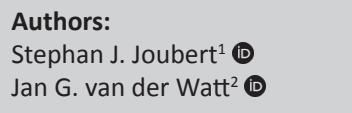 } \\
\hline \multicolumn{2}{|c|}{$\begin{array}{l}\text { Affiliations: } \\
{ }^{1} \text { Department of } \\
\text { Contemporary Ecclesiology, } \\
\text { Faculty of Theology, } \\
\text { University of the Free State, } \\
\text { Bloemfontein, South Africa }\end{array}$} \\
\hline \multicolumn{2}{|c|}{$\begin{array}{l}{ }^{2} \text { Department of } \\
\text { New Testament Studies, } \\
\text { Faculty of Theology, } \\
\text { University of the Free State, } \\
\text { Bloemfontein, South Africa }\end{array}$} \\
\hline \multicolumn{2}{|c|}{$\begin{array}{l}\text { Corresponding author: } \\
\text { Stephan Joubert, } \\
\text { sjoubert12@gmail.com }\end{array}$} \\
\hline $\begin{array}{l}\text { Dates: } \\
\text { Received: } 20 \\
\text { Accepted: } 09 \\
\text { Published: } 30\end{array}$ & $\begin{array}{l}\text { ept. } 2021 \\
\text { Oct. } 2021 \\
\text { Nov. } 2021\end{array}$ \\
\hline \multicolumn{2}{|c|}{$\begin{array}{l}\text { How to cite this article: } \\
\text { Joubert, S.J. \& Van der Watt, } \\
\text { J.G., 2021, 'Stephan J. Joubert } \\
\text { (South African academic } \\
\text { and visionary): His response } \\
\text { to questions related to } \\
\text { his academic views', HTS } \\
\text { Teologiese Studies/Theological } \\
\text { Studies 77(4), a7147. https:// } \\
\text { doi.org/10.4102/hts. } \\
\text { v77i4.7147 }\end{array}$} \\
\hline \multicolumn{2}{|c|}{$\begin{array}{l}\text { Copyright: } \\
\text { (c) 2021. The Authors. } \\
\text { Licensee: AOSIS. This wor } \\
\text { is licensed under the } \\
\text { Creative Commons } \\
\text { Attribution License. }\end{array}$} \\
\hline \multicolumn{2}{|l|}{ Read online: } \\
\hline 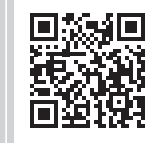 & $\begin{array}{l}\text { Scan this QR } \\
\text { code with your } \\
\text { smart phone or } \\
\text { mobile device } \\
\text { to read online. }\end{array}$ \\
\hline
\end{tabular}

This article reflects a conversation between Jan G. van der Watt and Stephan Joubert. The article serves as the introduction to the Special Collection: 'From timely exegesis to contemporary ecclesiology: Relevant hermeneutics and provocative embodiment of faith in a Corona-defined world - Festschrift for Stephan Joubert, sub-edited by Willem Oliver (University of South Africa)'. Following a brief bio-statement as introduction, the following issues are discussed: the collection for the Jerusalem church; relevance of theology for society; social-scientific exegesis; the ancient concept of grace; Bible translation in South Africa; public theology on the electronic platform; biblical examples of leadership and electronic media in religious activities and education.

Contribution: This Festschrift represents current trends in biblical scholarship and ecclesial leadership. It contributes to the public discourse in church and society, especially the role of the electronic media in current Fourth Industrial Revolution.

Keywords: Pauline studies; collection; patronage; social sciences and New Testament exegesis; electronic media and church.

\section{Introduction}

Stephan Joubert was born on 24 October 1958 in Kempton Park, South Africa. He studied at the University of Pretoria where he eventually obtained his DD degree (1987) under the supervision of Prof A.B. du Toit, and in 2012, he completed his PhD at Radboud University, Nijmegen, the Netherlands.

After serving as minister from 1988 to 1990, he was appointed as an associate professor in the Department of Biblical Studies at the Faculty of Theology of the University of Pretoria. In 1994, he was promoted to professor and head of the department. In 1997, he moved to the Department of New Testament Studies where he served as professor until his departure to New Zealand in August 2002. There he worked as minister of the Afrikaans Church of New Zealand until September 2003. He returned to South Africa in October 2003 and founded the E-Church (ekerk) of which he is still the director. Since then, he also assisted in several congregations as part-time minister and is a regular contributor to magazines and daily newspapers.

Back in South Africa he was also appointed as extraordinary professor in Contemporary Ecclesiology at the University of the Free State in 2011 and held a similar position in Theology at the University of the North West (2013-2018). He also joined Radboud University as a research fellow, assisting in the PhD programme from 2010 to 2017. As a guest professor, he lectured at several universities, for instance, the Christian University of St. Petersburg (Russia), the Universities in Würzburg and Wuppertal (Germany) and Radboud University (The Netherlands).

He was also awarded the Alexander von Humboldt International Research Award, Germany, in 1997, the Andrew Murray award for the best religious publication of the year twice $(2000,2010)$ and the Van Drimmelen medal from the South African Academy of Science and Art for the translation of the New Testament from the original Greek into Afrikaans in 2000.

Note: Special Collection: From timely exegesis to contemporary ecclesiology: Relevant hermeneutics and provocative embodiment of faith in a Corona-defined world - Festschrift for Stephan Joubert, sub-edited by Willem Oliver (University of South Africa). 
Stephan Joubert remained academically active throughout his career, as is evident from the list of publications at the end of this article. He made some important contributions not only in the field of New Testament but also across other disciplines involving leadership and the current technological revolution. In order to acknowledge his contributions, it was decided to go into discussion with him, giving him a chance to expand even further on his work, as well as reflecting on his current way of thinking. What follows are a number of questions about his work, also giving him the opportunity to share his current thoughts on these issues. This is followed by his list of publications.

Question 1: Professor Joubert, you are perhaps best known in academic circles for your contributions on the issue of the collection for the Jerusalem church, which you interpret within the framework of ancient social phenomena like benefactorism and patronage. Apart from your book (number 77 in the list of publications), you have published numerous articles (e.g. numbers 2, 5, 25, 28, 30, 32, 33, 35, 59, $60,62,67,68,70$ in the list of publications) on this issue that was responded to by others interested in this issue. As your contribution was instrumental in the ensuing dialogue, please give us your perspective on the current standing of the debate and your position within that debate.

Two approaches to the collection dominated the second half of the previous century. Firstly, the collection was understood as an eschatological undertaking in fulfilment of Old Testament prophecies regarding the nations' end-time pilgrimage to the City of David. From this perspective, the Pauline collection had to provoke an eschatological conversion of Israel. Secondly, it was understood as a caritative project to give visible expression to the bond of koinonia between Jerusalem and Pauline Christianity. These views, as well as many modified and refined versions thereof, were challenged, expanded and even replaced in recent years. I am grateful that my monograph in 2000 made a small contribution in this regard. Today Paul's collection for Jerusalem has even turned into somewhat of an academic hotbed for researchers to test out new theories and ideas related to the apostle's theology and new understandings of early Christianity. Post-colonial, materialist and socialscientific analyses, coupled with new approaches to ancient benefaction and early Christian leadership, have all been used to come to terms with this innovative project to which Paul devoted so much of his time, energy and thought.

I am convinced that Paul's collection should be understood primarily in terms of the social convention of benefit exchange. Reciprocity was at the heart of all forms of benevolence in the ancient Mediterranean world. Any bestowal of gifts or services between individuals and/or groups initiated the establishment of specific long-term relationships that involved mutual obligations and clear status differentials between the various transactors. Although reciprocity functioned on different levels in ancient Graeco-Roman and

1.The relevant articles, related to the specific question, are indicated by revering to the number of a particular article(s) in Appendix 1.
Jewish societies, it always boiled down to the basic fact that when something was received, something also had to be reciprocated. From this perspective, benefit exchange provided the basic interpretative framework for Paul to come to terms with his own obligation to address the needs of the poor in the Jerusalem church. At the same time, it also provided the basis for Paul's own reflections on the collection, such as the theological nature thereof that is based on the reciprocal relationship between Christ and believers (2 Cor 8:9); the principle of balanced reciprocity or 'equality' inherent in the exchange of material and spiritual gifts between Paul's churches and the Jerusalem church (2 Cor $8: 13-15)$ and the expected expressions of gratitude and the ensuing prayers of thanksgiving after the eventual delivery of the collection (2 Cor 9:11-15).

In terms of placing the collection within the framework of benefactorism, my own critique of the very high levels of abstraction at which many scholars investigate the relational dominance of reciprocity in the ancient Mediterranean world, as well as its formative impact on early Christian communities, provoked some interesting new academic discussions. I am convinced even more than ever that the general understanding of patronage, in particular, has acquired such a broad definition in research that it began to fit virtually every single form of reciprocal exchange in biblical texts. As a matter of fact, it has become generic enough to describe nearly any asymmetrical relationship cross culturally throughout history. Such a generalised application of patronage obscures the marked differences between the various ancient social exchange relationships it purports to describe, particularly, the differences between Hellenistic benefaction and Roman patronage. Various ancient sources point to the fact that patronage was not a generic term that randomly included Greek benefaction and all other forms of asymmetrical reciprocity as well. The relationship between a patronus and cliens involved specifically Roman practices that were not always prevalent in Greek societies around the time of the first century.

I was encouraged by the fact that recent historical studies of Roman patrocinium and Greek euergetism have identified many inherent differences between them on various levels of literary, historical and cultural abstraction to warrant not bundling them together under the popular scholarly rubric of 'ancient patronage'. Indeed both patronage and euergetism were asymmetrical relationships with particular disparities between the parties involved in terms of access to goods and services, as well as the public expressions of honour expected in return. However, many pointed differences between them, ranging from the nature of the ensuing relationships (i.e. the individual relationships in interpersonal patronal exchanges, versus general forms of public benefaction), to differences in the type of benefits exchanged, were now placed on the table. Fortunately, biblical scholars also began to apply these findings in much more nuanced ways in their studies of the New Testament (e.g. Briones 2013; Marshall 2009). 
Question 2: Lately, your interests also focused strongly on public theology, that is, the relevance of theology for society. What would you describe as the relevance of your research on the collection for society today?

The global corona pandemic has irrevocably changed the shape of our planet and all of its inhabitants. Hopefully, our rather disengaged, 'objective' ways of practising theology have also reached an unplanned expiry date. In this regard, it would be wise for us to learn from Paul and other theologians of the Bible whose embodied theologies directly shaped their own, as well as other believers' involvement in, and care for the poor and the impoverished during times of famine and other pandemics. In particular, Paul's 'first responder' stance when a huge famine struck Judea somewhere around $44-48 \mathrm{AD}$, as well as his extended collection for Jerusalem between 48 and 57 AD, should grasp our theological imagination once again.

Paul was no systematic theologian in the modern sense of the word. It would actually be anachronistic to think of him in such a way. His theological reflections were entrenched in his servant-like 'followership' of Christ. It was also reflected in his leadership, as well as in his personal involvement in these two collections for impoverished believers in Judea. More to the point, a 'preferential option for the poor', inherent in his theology influenced the organisation of these impactful collections for the poor on a scale basically unheard of in his own day. Amid Paul's strenuous work of planting churches right across the Roman Empire, while working as a manual labourer to provide for his own daily living and for that of his helpers, he never let go of his vision to see through this collection. In the end, it took him nearly a decade to complete this ambitious caritative undertaking. It was definitely no secondary add-on or some nice-to-have project. As a matter of fact, the collection served as a concrete expression of believers' koinonia and diakonia as it involved Christians from diverse cultural, social and geographical contexts right across the entire Roman Empire. While alleviating the plight of the poor, it visibly expressed the very nature of the theology Paul practised and preached.

Here and now the collection still serves as a timeless, yet timely, example of how our own theologies should have a direct impact on addressing the basic needs of others during calamities. By 'mimetically synchronising' with Paul's response to a devastating famine in his day, analogous responses to the corona pandemic here in our day should be pursued as a matter of urgency. The how and what' of such responses differ from situation to situation, but the necessity thereof in terms of personal involvement in the suffering of people should be nonnegotiable.

Question 3: You are also known for your constructive work in the field of social sciences (i.e. the Context Group; numbers $6,7,18,20,64,78$ in the list of publications), which obviously overlapped with your interest in the collection for the Jerusalem church. Your interest also branched out to cover interesting interfaces between physical behaviour and social perceptions formed about a particular person (numbers 44, 46, 49, 72, 73 in the list of publications). Could you please reflect on the exegetical significance of these insights and whether such insights could be of any hermeneutical value for present-day believers?

A few years ago, while reading O'Sullivan's monograph, Walking in Roman Culture, a new world opened up in front of me. It convinced me more than ever that the ancient Mediterranean world was a 'physiognomically conscious' world. Here it was widely accepted that individuals' appearance and physiology served as outward indications of their character. On the basis of these stereotypes, one could actually make judgements regarding other people's inner disposition. Simultaneously, one could also take a peek into their souls by carefully observing their bodily gestures. It was generally assumed that one's gait visibly revealed one's identity. Gait was more or less an expression of one's character in motion. For instance, nobles walked differently from and also somewhat slower than ordinary people, with their heads and shoulders upright to visibly express their superiority. In turn, slaves always went about in a hurry, hence the well-known expression: servus currens, the running slave.

This information triggered me to reread references to the physical appearance and gait of Paul in 2 Corinthians 10-13, as well as that of Jesus in the Gospel of Mark. For instance, the Markan Jesus is constantly on the move (e.g. Mk 1:9, 12, $14,21,29,35 ; 2: 13,23)$. There are no less than 17 references to

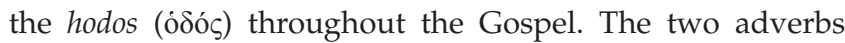

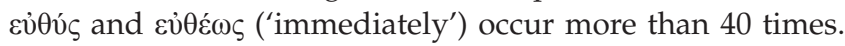
These descriptions of a 'fast-paced' Jesus are more than just a literary motif in Mark. In this 'physiognomically conscious' world where anything from bodily posture, movement and gesture served as outward indicators of a person's identity, character or status, the Markan Jesus looked and walked much differently from the typical honourable Mediterranean male. In slave-like fashion, he always hurried around and drew attention to himself. However, this atypical 'Jesus walk' and demeanour, which was defined by his humility and urgency, reflected his true inner character as he tells his disciples in Mark 10:45. Clearly Jesus did not come to be served but to serve. His outward appearance was definitely not a mask that was donned in public and removed again in private. It was no stage role either.

Simultaneously, Paul's well-known 'hymn' in Philippians 2:5-11 offers a similar description of the slave-like $\mu о \rho \varphi \eta$ ('morfe' $e^{\prime}$ ) or outward form of Christ whilst he was on earth. Contrary to the radiant posture and movements associated with the eminent presence of Graeco-Roman deities, Paul, just like Mark, did not place any emphasis on a glorious outward appearance of Christ either. Contrary to the anthropomorphic shapes of Graeco-Roman deities, who did not merely imitate the human bodily form, but always

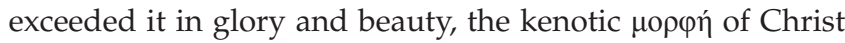
did not possess any such external identifying features. As a 
matter of fact, Christ physically emptied himself of all divine glory by associating fully with humanity's plight. It is precisely this kenotic life of Christ that serves as a testimony to his true identity, one that now becomes the normative paradigm for the Philippians to emulate.

Sadly, Paul's 'upside down' understanding of reality, based on Christ's humiliation and death on the cross, which also gave rise to a new ethos based on the status reversals of Christ and his self-denial on behalf of others, was turned upright again in many religious circles throughout the centuries. Time and time again, Jesus was turned into the likeness of a Graeco-Roman deity or a superhero figure here in our day. We now live in a culture obsessed with superheroes who are dressed in extravagant costumes to complement their superpowers. They have become our new mythologies. The Gospel of Mark, in particular, poses a serious challenge to this superhero culture. Contemporary followers of Jesus need to mirror themselves in this gospel where Jesus' atypical outward appearance and his radical teachings on self-sacrifice and his shameful death open up an entirely different world in front of us. As I have stated elsewhere:

In terms of the present obsession with superheroes, Jesus was never in a costume in public. He did not take on a temporary public persona in a staged drama en route to the cross. At all times, Jesus was the slave-like Son of God who came to serve and lay down his own life as a ransom for many (Mk 10:45). The crucified Jesus, stripped of all honour and godforsaken, is the paradoxical sign and physical embodiment of the kingdom of God. The risen Jesus is no different. He still is who he is. This largely undiscovered Jesus of Mark's Gospel must capture the imagination of the church all over again, the kind of imagination that elicits admiration, amazement and life-change. Only when the church begins to embody the kenotic route of Jesus that it will become clear to her and others that she, in fact, possesses paradoxical 'superpowers' - the self-sacrificing kind. (Joubert 2019:xxx)

Now it is all about losing the cape. It is about faithfully following in the footsteps of Jesus by surrendering ourselves in selfless service to God and others. As participants in the missio Christi, we need to emulate his walk towards the needy, the lost, the hungry and the outcast. We have to transform our surroundings by proclaiming and embodying the kingdom of God.

Question 4: Your views on grace (charis - numbers 29, 61 in the list of publications) also played a role in the wider academic reflection on this issue. It also became one of the key themes in your public theology. What would you describe as the key characteristics of grace and can one apply the ancient concept of grace to present-day people?

The concept of grace or charis ( $\chi$ ópls) is central to Pauline studies, as the informative monograph of John Barclay (2015) has recently shown. Since Paul also uses this term to refer to the collection, it is no surprise that a scholar such as Harrison (2003) understood the entire collection as a visible act of divine benevolence. It is a clear-cut sign of God's grace, one that addresses the physical needs of people while also helping the various participants to view themselves as recipients of God's charis. However, by means of his emphasis on God's infinite charis, Paul constantly challenges one of the basic assumptions of Graeco-Roman world, namely that reciprocity formed the backbone of all forms of social and religious interactions. Paul clearly knows that God, as the supreme divine benefactor, stands above this deeply embedded system of benefaction ( $\mathrm{Rm}$ 11:33-37). He places all recipients of his benefactions in permanent debt to Him. Therefore, constant gratitude on the side of believers for God's unmerited charis are called for by Paul, ranging from prayers of thanksgiving (1 Th 5:18) to public expressions of gratitude by doing everything to the honour of God (1 Cor 10:31).

Paul's soteriological understanding of charis as God's proactive power, which is revealed in his performative act of declaring sinners righteous through faith in Christ, should still be at the heart of our own understanding of his theology here in the 2020s. Charis is about God's eschatological gift in Christ. Therefore, recipients of charis must know that it is a 'costly' divine undertaking. They need to be challenged by the inescapable fact that a life in accordance with the gospel of Paul is the only fitting expression of gratitude to his 'amazing grace'.

Question 5: You have played a key role in Bible translation in South Africa (numbers 36, 74, 83 in the list of publications) and also won an award for your contribution. In light of your wide practical experience in translating the New Testament, please reflect academically on your view of what a Bible translation should be.

This is perhaps not only the most difficult but also the most fulfilling facet of my own life - being involved in the translation of the New Testament. Together with yourself as a close friend and colleague, we set out in the mid-1990s to translate the New Testament into a fresh Afrikaans vernacular. In spite of being investigated by some church authorities for daring to translate the Bible without 'official' permission from their synod, 'Die Boodskap' was a success. Ever since its publication in 1997, it has sold somewhere in the region of a million copies.

I am well aware of the fact that the translation of the Bible is always a contentious issue. As the basis text of Christianity, the Bible gives formal expression to the faith, hopes, morals and beliefs of believers and was accepted as such throughout the ages. Perhaps this is why many Bible translations tend to be rather conservative in their approach. The King James' Version, the American Standard Version, the 1953 Afrikaans Bible Translation, as well as the new 2020 Afrikaans Translation, are all literal translations. They follow the syntactic and lexical meanings expressed in the source languages as closely as possible by endeavouring to translate every single word from Greek or Hebrew into an exact equivalent in the receptor language. 
Over against this, so-called formal-equivalent approaches or dynamic-equivalent approaches to Bible translation are much more 'receptor friendly'. For instance, in the New International Version (NIV) or the New Revised Standard Version the grammatical connotations, rhetorical impact and emotive meanings of the original texts are reflected to the best degree possible in the translations, but without slavishly following all the grammar characteristics of the original languages. The aim here for the translators is to have the same impact on modern audiences as the original texts had on their initial readers. Instead of translating every single word of the biblical texts into an exact equivalent in the receptor language, translators who adhere to the basic principles of dynamic equivalence endeavour to produce the closest possible equivalents of the meanings encoded in the original language structures.

When we translated 'Die Boodskap', as well as 'Die Bybel@ Kinders' together with Hennie Stander and other scholars, our aims were exegetical reliability in terms of our understanding of the original languages within their original socio-historical settings, as well as idiomatic readability in terms the Afrikaans receptor culture. In other words, the exegetical meaning of the original texts, as well as on the question how this meaning may be expressed effectively in the target language informed our approach. One of the basic questions I constantly tried to address for myself during these translation processes was how would the documents of the New Testament sound like if they were originally written in modern Afrikaans? How would they describe concepts such as agape or love; how would they persuade, use idioms, reprimand, comfort, encourage and basically narrate the good news of Jesus?

Translators have to find the fine balance between being sensitive to the needs of the intended readers of translations while also respecting the right of biblical texts to be heard on their own terms as religious artefacts from different cultures. As already said, literal translations endeavour to translate the Greek or Hebrew into exact equivalents in any receptor language in order to faithfully preserve the 'true meaning' of Scripture, but without much consideration for the receptor language's own peculiarities, style and codes. In contrast, numerous modern translations of the Bible have removed the 'culture shock' effect inherent in the biblical texts. These biblical documents linguistically embody socio-religious meanings and forms of communication derived from ancient Mediterranean societies with some very different values and customs. Hence, they also need to be experienced as somewhat different (if not alien at times!) by readers of modern Bible translations.

Question 6: You are one of the most influential, if not the most influential, public theologians in South Africa at this point (e.g. numbers 13, 34, 41, 42, 45, 48, 50, 51 in the list of publications). Your publications (both books and regular articles in magazines and daily newspapers) and the influential electronic platform, that is, ekerk, which you started 17 years ago vouch for this. Judging from these, you firmly believe in the power of the Biblical message for social formation and positive change. Please reflect academically on (1) what you think public theology is, (2) how and where it should be done and especially (3) the hermeneutical restrictions and possibilities of applying the ancient text of the Bible on modern situations.

Public theology is not merely the popular face of theology something like 'theology for dummies' or 'theology made simple in a few easy steps'. At the same time, it entails much more than popular discussions of contemporary theological issues on various public platforms or formal declarations when moral issues are at stake in the church and elsewhere. Public theology should also not be confused with generalised applications of theological ideas and biblical principles for the sake of the general public out there, as if it is the responsibility of the public theologian to ensure a continued popular interest in theological issues.

Public theology is first of all embodied theology. It is about shifting from that deeply entrenched critical observer mode to an embodied responsiveness in terms of the core message of the Bible and contemporary realities. While constantly being 'reread' and 'redefined' by the Bible, public theologians intentionally endeavour to embody, understand and communicate the Bible in hermeneutically responsible ways here and now.

For public theologians, the Bible is more than a 'go-to' book to run to whenever answers are needed or a bundle of 'prooftexts' that have to be used at will in public debates. They constantly immerse themselves in the Bible. They imbed their lives in the narratives of Jesus, as well as the other biblical narratives. From this perspective, they also communicate the new plot and the larger hermeneutical context within which the life stories of contemporary Jesus followers need to be situated. Elsewhere I have described the nature of this so-called 'ancient-future approach to the Bible' in the following manner:

Time and again we have to inquire of the Word and of the first believers with regard to our roots, our path, our oxygen, our food and our direction. We have to capture the rhythm of biblical folk by reversing to advance. With all that knowledge, narratives, lessons, norms and experiences, we have to live backwards and forwards simultaneously. To master this rhythmic motion of advancing and reversing, it is necessary to know how our ancestors in biblical times expressed their own crossroad experiences with Jesus. The life rhythms flowing from this offer precious lessons to contemporary spirituality (Joubert 2012:37).

Public theologians are well aware of the fact that Christianity has not lost its lure, but that formal theology and formal church, as her official custodians, have lost much of their influence and vibrancy. At times, it even seems as if the original gospel code has been mutated in their midst because they have chosen to be less adaptable to cultural changes in favour of entrenching their own traditional roles as 
gatekeepers of a fast-shrinking religious and theological status quo. Often, these systems have become inherently consumptive. While church members have to 'get fed spiritually' in consumer-driven church environments, formal theology has also become an end in itself. In such contexts, it is all about the number of publications, positive peer reviews and the recognition of like-minded theologians. Therefore, effective public theologians are never confined to the same silos in which many churches and theologians find themselves. They challenge the religious and theological stereotypes inherent in these systems, but they always do this from the perspective of concerned insiders, and never as detached, critical outsiders. They are like Trojan horses in formal theological and religious institutions with all their fixed structures, dogmas, solidified rituals and prestigious academic enclaves. They refuse to fall into the typical entrapments of stereotypical dichotomies such as 'theologyversus-church' or 'scholar-versus-practitioner'.

At the same time, as missionaries to modern culture in whatever shape, size or form, public theologians engage in the creation and/or communication of vibrant new theologies and relevant ecclesiologies on all possible platforms. From this perspective, I concur with Andries van Aarde (2008): 'The social location of public theologians is not the university campus, but rather the public square - in other words, the modern-day agora - wherever it may be situated in the "global village" or in the "cyber space". In such spaces, it is always about more than formal dialogues or yet another session of public discussions. It is about an embodied, first responder presence in lecture halls, boardrooms, coffee shops, squatter camps, church services and different digital platforms.

Question 7: Leadership is one of your interests (numbers $35,40,49,81$ in the list of publications). Is it justified to responsibly motivate current leadership roles in terms of biblical figures or material?

The danger of anachronism always looms large on the horizon when biblical examples of leadership are uncritically applied as prototypes to be emulated in contemporary situations. As a result of such overhasty applications, what is frequently referred to as 'biblical leadership principles' on the one hand, or a total neglect of applicable norms embedded in biblical narratives on the other hand, the kind of leadership observed in many churches today often tends to be influenced more by the latest business trends in society and in popular leadership books or by dated religious traditions than anything else. Fortunately, all of this does not imply that the norms and lessons embedded in narratives and other texts in the Bible that address leadership in whatever forms are not applicable in contemporary situations. Here nuanced hermeneutical approaches are called for in order to traverse responsibly and carefully between the textual worlds of the Bible and contemporary realities.

In the New Testament, leadership is always a function rather than a formal position. It is a role rather than an identity. First and foremost, all believers are called to follow Jesus as Leader, Teacher and Lord. However, the persistent undertones of heroism inherent in the classic ideal of the significant individual who always facilitates effective change and who always saves the day, which is prevalent in most spheres of society, has also infiltrated religious circles. This perception, which has also given rise to the vices of entitlement, control and prestige in religious circles, has to be challenged by effective, selfless leadership. Such leadership is not about positions of power or opportunities for selfenhancement.

Selfless leadership is embedded in the example of Jesus. In the Gospel of Mark in particular, his inglorious outward appearance as the 'running slave of God' and his servant-like behaviour and teachings confront his disciples with new roles. Throughout Mark, the disciples struggle to grasp the true identity of Jesus. This is illustrated, among others, by the request of James and John for the two most important seats in God's heavenly kingdom (Mk 10:35-40). In response, Jesus stresses that the greatest amongst them should now become their servant (Mk 10:43). To this, he adds the role of the slave as well: 'Whoever wants to be first amongst you is to be slave of all' (Mk 10:44).

It was common-sense knowledge that slaves did not have any honour. Their cowering postures, hurried movements, humble garments and silenced tongues all pointed to the fact that they did not demand any form of public respect or honour. Jesus' disciples have to follow suit by taking up the role of slaves. In our modern world that is obsessed with outward appearance and success, the challenge facing leaders who claim that they follow Jesus is to embody the humble roles of servants and slaves. Such leaders do not follow carefully scripted career paths in order to attain recognition, power, financial benefits or personal fame at the expense of others. They follow a lifelong vocation. Rather, their vocation chooses them. They are summoned to lead. In fact, they have no choice in the matter. They know that such a calling of selfless service goes against the grain of highly competitive contemporary business and religious cultures. However, they have no other option but to cultivate their gifts, their training and their wisdom in order to be of service to others and to honour God. Selfless leadership in whatever guise, expression or profession is about helping others reach their potential and fulfil their own calling before God.

Question 8: You are indeed a pioneer in the South African context when it comes to the use of electronic media (numbers 41, 42, 45, 48, 50 in the list of publications), especially as key figure in the successful ekerk, an electronic vehicle providing a variety of information, interaction and even practical involvement on Christian religious level. Part of this is also the 'Learning Community' through which you provide high-level academic information to religious professionals through conferences (also electronically). Please reflect on the future of electronic media in religious activities and education. How can the 
integrity of Christian material be safeguarded against excessive popularising and 'fake news' in the sense of unmotivated, irresponsible or negatively biased material that might also appear on the web.

Annus virtualis has dawned on all of us. Cyberspace has become our new frontier, one where nearly all traditional boundaries have become porous and blurred. Technology is rapidly changing how people live, work, think, interact and also give expression to their faith. Everywhere people participate in online business, entertainment, education, religion, medical services, sports, news, shopping, gaming, studies, cyber-socialisation, etc., but without all the restrictions and restraints of time and physical space. No wonder we all walk around with mini-computers in our pockets called cell phones, which filter large parts of our daily lives!

Clearly, churches are not exempt from all these technological changes. Especially, because the outbreak of the coronavirus churches everywhere were forced to go online. The distinction between 'online religion' (which is mainly about the 'provision of information about and/or services related to various religious groups and traditions') and 'religion online' (which is about inviting internet visitors 'to participate in religious practices' - Dawson \& Cowan 2004:6), has suddenly become outdated. The days of unmediated, technology-free faith formation are over. Now, more than ever, all of reality plays out on a continuum between virtual and real spaces.

Digital faith communities are no longer just 'nice to haves' or 'add ons' to 'real' churches; they have become emergent realities in their own right. They are here to stay. As a matter of fact, according to church analyst Carey Nieuwhof (2020:n.p.), 'growing churches in the future will become digital organisations with physical expressions, not physical organisations with a digital presence'. Churches and theological institutions that do not facilitate a transparent and relevant digital presence will lose out - as simple as that! Online access to home-based training programmes, academic courses, study material, Bible studies, sermons and internet resources, coupled with assistance from flexible and agile virtual teams, will be the new game changers in this regard. However, we should not be blind to the many challenges posed by shifting our lives and our faith online. We have to be aware of the fact that (Gackenbach \& Bown 2017):

$[A] \mathrm{s}$ technology has aided humans to transcend the limit of their physical bodies, the Internet, digital media and VR [virtual reality] technologies are already chipping away at the illusions of individuality and the self. (xxiv)

Digital and non-digital subjectivities, with their often contradictory values, are busy carving out new identities for millions, that is, new biological selves and digital selves.

Sherry Turkle, social psychologist and professor at MIT, also warns that social media offers 'the illusion of companionship without the demands of friendship'. Digital 'friends' and 'followers' with their endless 'likes' and positive emoji's, far too easily turn into new significant others. Many buy into the idea that the more 'connected' or 'plugged in' we are on social media, the less alone we will be. However, most of these digital friends seldom, if ever, rise to any occasion when they are really needed. At the same time, Jean Twenge (2013) also points to a significant growth in narcissism among the online generation, one that is associated with a loss of empathy and a diminished capacity for self-reflection.

In spite of these and numerous other challenges, cyberspace should be embraced. It should become the new sacred space of faith communities, one that is infused with solid biblical content, integrity, transparency and meaningful relationships. To this effect, churches should put relevant digital ministries in place, ones that also teach believers some basic digital skillsets, such as how to recognise and sidestep fake news and how to interact effectively online. Believers' imagination should intentionally be shifted towards a new understanding of their own online activities as being an integral part of their spiritual lives. The focus should be on the formation of a more holistic faith, one that does not divide people's digital presence from other forms of presence elsewhere. In terms of our ekerk I have explained it as follows (2018):

We do not want to create a digitally driven religious ghetto, or a high-speed 'Christianized, Google-like platform', where questions could be answered and problems solved at cyber speed. Online community is never a replacement for the physical community of believers. Therefore, ekerk's continued involvement with local churches and academic places of learning. It is no longer an 'either or', but a 'both and'. In this era of liquid modernity, we have to embrace the fact that our most recent ecclesiologies, as expressions of our embeddedness in contemporary culture, is conditioned, contingent and liquid. It will evolve, grow or even shrink as we continue to make sense of a world where theology will probably entail more than simply faith-seeking understanding, as Anselm of Canterbury famously said many moons ago. Perhaps theology must now also explicitly include notions of 'faith-seeking experience', or 'faith-seeking community'.

\section{Acknowledgements Competing interests}

The authors declare that they have no financial or personal relationships that may have inappropriately influenced them in writing this article.

\section{Authors' contributions}

I (S.J.) have addressed all questions posed to me by Prof Jan van der Watt in this interview, in an autobiographical manner. I framed my answers in academic terms and endeavoured to conceptualise my reflections in terms of larger conceptual and hermeneutical frameworks. 


\section{Ethical considerations}

This article followed all ethical standards for research without direct contact with human or animal subjects.

\section{Funding information}

This research received no specific grant from any funding agency in the public, commercial or not-for-profit sectors.

\section{Data availability}

Data sharing is not applicable to this article as no new data were created or analysed in this study.

\section{Disclaimer}

The views and opinions expressed in this article are those of the authors and do not necessarily reflect the official policy or position of any affiliated agency of the authors.

\section{References}

Barclay, J.M.G., 2015, Paul and the gift, Eerdmans, Grand Rapids, MI.
Briones, D.E., 2013, Paul's financial policy: A socio-theological approach, Bloomsbury T \& T Clark, London.

Dawson, L.L. \& Cowan, D.E. (eds.), 2004, Religion online: Finding faith on the internet, Routledge, London.

Gackenbach, J. \& Bown, J., 2017, 'Introduction', in J. Gackenbach \& J. Bown (eds.), Boundaries of self and reality online: Implications of digitally constructed realities, pp. xxiii-xxvi, Elsevier Academic Press, London.

Harrison, R.J., 2003, Paul's language of grace in its Greco-Roman context, Mohr Siebeck, Tübingen.

Joubert, S.J., 2012, Jesus: Radical, righteous, relevant, Christian Art Publishers, Vereeniging.

Joubert, S.J., 2018, “"Flowing” under the radar in a multifaceted liquid reality: The ekerk narrative', HTS Theological Studies 74(3), 4966. https://doi.org/10.4102/ hts.v74i3.4966

Joubert, S.J., 2019, 'Invited into the Markan paradox: The church as authentic followers of Jesus in a superhero culture', HTS Theological Studies 75(3), a5399. https://doi.org/10.4102/hts.v75i3.5399

Marshall, J., 2009, Jesus, patrons and benefactors: Roman Palestine and the Gospel of Luke, Mohr Siebeck, Tübingen.

Nieuwhof, C., 2020, The original 2020 is history. 7 New disruptive church trends every church leader should watch, viewed 12 January 2021, from https://careynieuwhof. com/the-original-2020-is-history-7-new-disruptive-church-trends-every-churchleader-should-watch/.

Twenge, J.M., 2013, 'Does online social media lead to social connection or social disconnection?', Journal of College and Character 14(1). https://doi.org/10.1515/ jcc-2013-0003

Van Aarde, A.G., 2008, "What is "theology" in "public theology" and what is "public" about "public theology?", HTS Theological Studies 64(3), a81. https://doi. org/10.4102/hts.v64i3.81 


\section{Appendix 1: List of publications: Stephan Joubert}

\section{Essays in academic journals}

1. 1988a, 'Die Judasbrief: ' $n$ Simboliese universum in die gedrang', HTS 44, 613-635.

2. $1988 \mathrm{~b}$, 'Die tekstuele strategie wat Paulus in 1 Korintiërs 16:1-4 ter organisering van die kollekte vir die gemeente in Jerusalem volg', NGTT 29, 120-128.

3. 1989, 'Die gesigpunt van die verteller en die funksie van die Jerusalemgemeente binne die "Opsommings" in Handelinge', Skrif en Kerk 10(1), 21-35. https://doi. binne die "Opsommings" in
org/10.4102/ve.v10i1.995

4. 1990a, 'Language, ideology and the social context of the letter of Jude', Neotestamentica 24, 335-349.

5. 1990b, 'Armoede en eenheid: Die Pauliniese kollekte vir die Jerusalemgemeente en enkele implikasies hiervan vir die N.G. Kerkfamilie', NGTT 31, 89-98.

6. 1991, "n Verruimde invalshoek tot die verlede? Die sosiaal-wetenskaplike benadering tot die Nuwe Testament', HTS Theological Studies 47, 39-54.

7. 1992a, 'Van werklikheid tot werklikheid: Die interpretasie en interkulturele kommunikasie van Nuwe-Testamentiese waardes', Scriptura 41, 55-65.

8. 1992b, 'Nuwe-Testamentiese perspektiewe op egskeiding', Skrif en Kerk 13(1), 27-40. https://doi.org/10.4102/ve.v13i1.1045

9. $1992 \mathrm{c}$, 'Behind the mask of rhetoric: The intra-textual relationship between Paul and the Corinthians in 2 Corinthians 8', Neotestamentica 26, 101-112.

10. 1992d, 'Wanneer die onmoontlike moontlik word: Paulus as verkondiger en boue van 'n nuwe universum', NGTT 33, 301-310.

11. 1992e, "'Op maat van die musiek: Die lewende familie van Christus in Filippi", in J.C. Breytenbach \& B.C. Lategan (eds.), Geloof en opdrag: Perspektiewe op die etiek van die Nuwe Testament', Scriptura 9a, 164-180.

12. 1993a, 'Meestersimbool van 'n nuwe werklikheid: Jesus van Nasaret en die koninkryk van God volgens die sinoptiese evangelies', In die Skriflig 27, 91-107.

13. 1993b, 'A bone of contention in recent scholarship: The "Birkat ha-Minim" and the separation of church and synagogue in the first century AD', Neotestamentica 27 , 351-363.

14. 1993c, 'Jesus van Nasaret se bevrydende visie vir ' $n$ gewelddadige samelewing', Skrif en Kerk 14(2), 222-235. https://doi.org/10.4102/ve.v14i2.1069

15. 1994a, 'Rituele en seremonies: Van toe tot nou', Praktiese Teologie in Suid Afrika 9, $72-82$.

16. 1994b, 'A kaleidoscope of approaches: Paradigms, paradigm-changes and the "Umwelt" of the New Testament', Neotestamentica 28, 23-40.

17. 1994c, 'Beteken “Abba” regtig Pappa?', NGTT 35, 135-142.

18. 1995a, 'Persuasion in the letter of Jude', JSNT 58, 75-87.

19. 1995b, 'Much ado about nothing? In discussion with the study of Evert-Jan Vledder: "Conflict in the miracle stories in Matthew 8 and 9: A sociological and exegetical study"', HTS Theological Studies 51, 245-254.

20. 1995c, 'In gesprek met uiteenlopende werklikhede: Bybelkunde as 'n eiesoortige teologiese dissipline binne die veranderende Suid-Afrikaanse konteks', Skrif en Kerk 16(1), 67-81. https://doi.org/10.4102/ve.v16i1.440

21. $1995 \mathrm{~d}$, 'The Jerusalem community as a role-model for a cosmopolitan Christian group: A socio-literary analysis of the Lukan symbolic universe', Neotestamentica 29, 49-60.

22. 1996a, 'Van Henten, J.W. \& Joubert, S.J.: Two a-typical Jewish families in the Greco-Roman world', Neotestamentica 30(1), 121-140.

23. 1996b, 'Van der Watt, J.G. \& Joubert, S.J.: Hoe is Jesus gekruisig?', HTS Theological Studies 52(4), 633-652. https://doi.org/10.4102/hts.v52i4.1548

24. 1996c, "'Die huwelik in die Nuwe Testament”, in Müller, J. \& Vos, C. (reds.), Een maar twee', Praktiese Teologie in Suid-Afrika 11(2), 37-47.

25. 1997, 'Nuwe-Testamentiese perspektiewe op die sabbat en die Sondag', Skrif en Kerk 18(1), 97-110. https://doi.org/10.4102/ve.v18i1.1127

26. 1998a, 'Facing the past: Transtextual relationships and historical understanding in the Letter of Jude', Biblische Zeitschrift 42(1), 73-88.

27. 1998b, 'Antieke weldoenerskap en die interpretasie van die Nuwe Testament (Ancient benefaction and the interpretation of the New Testament)', NGTT 39(3), 154-161.

28. 1999a, "'Dit is hoog tyd dat ons iets oor die tyd sê." Nuwe-Testamentiese perspektiewe op die eindtyd', Skrif en Kerk 54, 93-106.

29. 1999b, "'Homo reciprocus": Seneka, Paulus en weldoenerskap', HTS Theological Studies 54(4), 1022-1038.

30. 1999c, 'Religious reciprocity in 2 Corinthians 9:6-15: Generosity and gratitude as legitimate responses to the "charis tou theou", Neotestamentica 33(1), 50-63.

31. 2000a, 'Patronatus as dominante sosiale sisteem in die Romeinse wêreld gedurende die Nuwe-Testamentiese era', Skrif en Kerk 21(1), 66-76. https://doi. org/10.4102/ve.v21i1.1183

32. 2000b, “'Is die duiwel los?" Nuwe-Testamentiese perspektiewe op die stryd tussen Christus en die Bose', In die Skriflig 34(2), 195-206.

33. 2000c, 'Romeine 15:22-33: Die Pauliniese kollekte as ' $n$ elfde-uur suksesverhaal', NGTT 41, 297-304

34. 2001a, 'One form of social exchange or two? "Euergetism," patronage, and Testament studies', Biblical Theology Bulletin 31(1), 26-37.
35. 2001b, 'Die relevansie van teologie in millennium drie', Verbum et Ecclesia 35(2), $1-11$.

36. 2001c, 'Die leierskap van die Jerusalemkerk as weldoeners tydens die ontmoeting met Paulus: Galasiërs 2:10 en antieke Joodse resiprositeit', HTS 57(3), 1213-1228.

37. 2001d, '1 Corinthians 9:24-27: An agonistic competition?', Neotestamentica 36(1), 49-56.

38. 2001/2002, 'No culture shock? Addressing the Achilles heel of modern Bible translations', Verbum et Ecclesia 35(3), 102-118.

39. 2002a, 'Aan tafel saam met Jesus: Eksegetiese riglyne vir prediking uit Lukas 14:124', NGTT 43(1), 76-82.

40. $2002 \mathrm{~b}$, 'When the dead are alive! The influence of the living dead in the letter of Jude', HTS 58(2), 576-592.

41. 2010, 'Annus Virtualis: Enkele uitdagings wat die virtuele era van Web 2.0 aan relevante kerklike bediening stel', NGTT 51(3/4), 48-60.

42. 2013a, 'Not by order, nor by dialogue: The metanoetic presence of the Kingdom of God in a fluid new world and church', Acta Theologica 33(1), 114-134.

43. 2013b, "'Seeing the error of my ways." Revisiting Paul's paradigmatic, self-critical remarks in 1 Corinthians 15:8-10', Acta Theologica 33(2), 74-89. https://doi. org/10.4314/actat.v33i2.5

44. 2014, “'Walking the talk:" Paul's authority in motion in 2 Corinthians $10-13$ ', In die Skriflig/In Luce Verbi 49(2), 7-15.

45. 2015, 'Joubert S.J. \& Schoeman W.J.: An exploration of the use of technology by congregations', Acta Theologica 22 (Suppl 1), 171-190. https://doi.org/10.4314/ actat.v21i1.11S

46. 2017, 'Embracing obscurity: The enigmatic walk of the Son of God in Mark', In die Skriflig/In Luce Verbi 51(3), a2100. https://doi.org/10.4102/ids.v51i3.2100

47. 2018a, 'When God alters our fate: Relational freedom in Romans 5:1-11 and 8:18-39, Stellenbosch Theological Journal 4(2), 223-241.

48. 2018b, "Flowing" under the radar in a multifaceted liquid reality: The ekerk narrative', HTS Theological Studies 74(3), 49-66. https://doi.org/10.4102/hts. v74i3.4966

49. 2019, 'Invited into the Markan paradox: The church as authentic followers of Jesus in a superhero culture', HTS Theological Studies 75(3), a5399. https://doi. in a superhero culture',
org/10.4102/hts.v75i3.5399

50. 2020a, 'Reclaiming our humanity: Believers as sages and performers of the Gospel in the era of the Fourth Industrial Revolution', HTS Teologiese Studies/Theological Studies 76(2), a5973. https://doi.org/ 10.4102/hts.v76i2.5973

51. 2020b, 'Embracing an embodied theology in a time of Corona: Mimetic synchronisation with the theological rhythms and first repsonder stance of the apostle Paul during the time of famine', HTS Teologiese Studies/Theological Studies 76(4), a6101. https://doi. org/10.4102/hts.v76i4.6101

\section{Contributions: Academic publications}

52. 1990, 'Dood na 'n ongeluk: 2 Korintiërs 4:7-18: 'n Troospreek', in C.J.A. Vos \& J.C. Müller (reds.), God, mens en wêreld. Boek 4: God en ons lyding, pp. 153-161, NG Müller (reds.), God, mens
Kerkboekhandel, Pretoria.

53. 1991, 'Voort met die nuwe bedeling: Handelinge as ' $n$ paranetiese narratief binne 'n kosmopolitiese Christelike gemeenskap,' in J.H. Roberts, W.S. Vorster, J.N. Vorster \& J.G. Van der Watt (reds.), Teologie in konteks: Feesbundel vir A. B. du Toit, pp. 131-155, Orion Publishers, Pretoria.

54. 1994, 'Die Christen as ' $\mathrm{n}$ herskepte mens', in C.J.A. Vos \& J.C. Müller (reds.), God, mens en wêreld: Menswaardig, pp. 199-207, Orion Publishers, Halfway House.

55. 1995, "Managing the household. Paul as "paterfamilias" of the Christian community in Corinth', in P.F. Esler (ed.), Modelling early Christianity, pp. 213223, Routledge \& Kegan Paul, London.

56. 1996, 'Christians: Disciples of Jesus', in P.G.J. Meiring (ed.), South Africa: Land of many religions, pp. 31-50, Dibukeng Publishers, Pretoria.

57. 1999, 'Handelinge', in F. Van Rensburg \& W. Vosloo (reds.), Die Bybellenium, pp. 1375-1447, Christian Art Publishers, Vereeniging.

58. 2000, 'Coming to terms with a neglected aspect of Ancient Mediterranean reciprocity. Seneca's views on benefit-exchange in De beneficiis as a model of social exchange', in J. Pilch (ed.), Social scientific models for interpreting the Bible. social exchange', in J. Pilch (ed.), Social scientific mode
Festschrift for Bruce Malina, pp. 47-64, Brill, Leiden.

59. 2003, 'Reciprocity and the poor among the first followers of Jesus in Jerusalem', in R.E. Averbeck, M.W. Chavalas \& D.B. Weisberg (eds.), Life and culture in the Ancient Near East, pp. 371-388, CDL Press, Bethesda, ML.

60. 2005a, "XARIS in Paul. An investigation into the apostle's "performative" application of the language of grace within the framework of his theological reflection on the event/process of salvation', in J.G. Van der Watt (ed.), Salvation in the New Testament, pp. 187-212, Brill, Leiden.

61. 2005b, 'Reconciliation in the apostle Paul: A divine gift for a new mankind, in J.G. Van der Watt, D. Human \& G. Steyn (eds.), Friendship and love where there were none: Biblical perspectives on reconciliation, pp. 112-122, In honour of Archbishop Desmond Tutu, Universiteit van Pretoria, Pretoria.

62. 2006, 'The collection of Paul', in The new interpreters' Dictionary of the Bible, pp. 42-51, Abingdon Press, Nashville, TN.

63. 2008, 'In sync with Jesus and the first perfect stormers', in L. Sweet (ed.), The church of the perfect storm, pp. 42-50, Abingdon Press, Nashville, TN.

64. 2009, 'Ontdek die vroeg-kerklike dinamiek van die erediens', in C. Wepener \& J. Van der Merwe (reds.), Ontdekkings in die erediens, pp. 51-68, Lux Verbi/BM, Wellington. 
65. Van Aarde, A.G. \& Joubert, S.J., 2009, 'Social-scientific criticism', in A.B. Du Toit (ed.), Focusing on the message: New Testament hermeneutics, exegesis and methods, pp. 419-456, Orion Publishers, Pretoria.

66. 2010, 'Nie meer Lone Rangers op kansels nie', in D. Bester, J. Cilliers \& I. Nell (reds.), Teen my $\sin$ en teen my beterwete: Kantaantekeninge oor preek en preekmaak, pp. 79-86, Bybelmedia, Wellington.

67. 2011, 'Paul's apocalyptic eschatology in 2 Corinthians', in J.G. Van der Watt (ed.) Eschatology in the New Testament, pp. 225-238, Brill, Leiden.

68. 2013, 'Benefactor', in D.C. Allison, H-J. Klauck, V. Leppin, C.L. Seow, H Spieckermann, B. Walfish, et al. (eds.), Encyclopedia of the Bible and its reception, pp. 114-116, Walter de Gruyter, Berlin.

69. 2014, 'Homo reciprocus no more: The "missional" nature of faith in James', in J. Kok, T. Nicklas, D.T. Roth \& C.M. Hays (eds.), Sensitivity towards outsiders: Exploring the dynamic relationship between mission and ethics in the New ck, Tübingen.

70. 2015, 'Patrocinium and euergetism: Similar or different reciprocal relationships? Eavesdropping on the current debate amongst biblical scholars', in M. Nel, J.G. World. Articles in Honour of Abe Malherbe, pp. 171-196, Lit Verlag, Zürich.

71. 2019, 'A well-played life: Discernment as the constitutive building block of selfless leadership', in J. Kok \& S.C. Van den Heuvel (eds.), Leading in a VUCA world: Integrating leadership, discernment and spirituality, pp. 139-150, Springer, Cham.

72. 2020c, 'Feeling, seeing and acting differently: The emotional disposition and actions of God in Luke 15:20 as A mimetic compass for the contemporary church in search of a vibrant faith', in C.A.M. Hermans \& Jan-Albert van den Berg (eds.), Battle for the heart: How (not) to transform church and society, pp. 31-48, Lit Verlag, Zürich.

73. 2020d, 'The Jesus walk as normative paradigm for the church: The Missio Christi in the Gospel of Mark', in W.J. Schoeman (ed.), Churches in the mirror: Developing contemporary ecclesiologies, vol. 4, pp. 57-74, University of the Free State Theological Explorations, Sun Media, Bloemfontein.

\section{Academic books (as author/editor)}

74. Joubert, S.J., 2000, Paul as benefactor. Reciprocity, strategy and theological reflection in Paul's collection, Mohr-Siebeck, Tübingen.

75. Joubert, S.J., 2014, Echoes of charis: Paul's contextual reflections on salvation, Lit Verlag, Zürich.

76. Joubert, S.J., 2015/2019, Ontsluit die Nuwe Testament, Christelike Uitgewers Maatskappy, Vereeniging

77. Joubert, S.J. \& Mare, L., 2015, Ontsluit die Bybel (Unlock the Bible), Christelike Uitgewers Maatskappy, Vereeniging.

78. Joubert, S.J., Van der Watt, J.G. \& Stander, H.F., 1999, Die Nuwe Testament vir kinders, Vereeniging, Carpe Diem.

79. Malina, B.J., Van der Watt, J.G. \& Joubert, S.J., 1995, Vensters wat die Woord laa oopgaan: Op besoek aan die antieke Mediterreense wêreld, Orion Publishers, Halfway House.

80. Malina, B.J., Van der Watt, J.G. \& Joubert, S.J., 1996, A time travel to the world of Jesus, Orion Publishers, Halfway House.

81. Meiring P.G.J. \& Joubert, S.J. (eds.), 1992, Fokus op die kerk: Die rol van die kerk in 'n veranderde Suid Afrika, Christian Art Publishers, Vereeniging.

82. Van der Watt, J.G. \& Joubert, S.J., 1996, Die Boodskap. 'n Nuwe Afrikaanse interpretasie van die Nuwe Testament, Christelike Uitgewers Maatskappy, Vereeniging.

83. Van der Watt, J.G., Joubert, S.J., Du Rand, J.A. \& Naudé, P., 2002, Hoe lees ons die Bybel? ' $n$ Soeklig op die rol van die Woord en hoe om dit te vertolk in hedendaagse tye, Christelike Uitgewers Maatskappy, Vereeniging.

84. Zimmermann, R. \& Joubert, S.J. (eds.), 2017, Biblical ethics and application Purview, validity and relevance of Biblical texts in ethical discourse, Mohr Siebeck, Tübingen. 